\title{
Establishment of Induced Pluripotent Stem Cells from Immortalized B Cell Lines and Their Differentiation into Cardiomyocytes
}

\author{
Emiko Hayama, Yoshiyuki Furutani, Nanako Kawaguchi, \\ Eiko Oomichi, Mitsuyo Shimada, Kei Inai, \\ and Toshio Nakanishi
}

Collection of peripheral blood from many patients over a long period of time has resulted in the establishment of a library composed of more than 4400 immortalized $\mathrm{B}$ cell lines, which have been used to identify mutated genes responsible for congenital heart defects (CHD). Because of the current progress in induced pluripotent stem cell (iPSC) technology and the ability of these iPSC lines to differentiate into cardiomyocytes, we started a project to establish an in vitro cardiac disease model using patient specific-iPSC-derived cardiomyocytes. As part of this project, we have established more than 20 iPSC lines from patients with CHD and from normal controls. All generated iPSC lines expressing pluripotent stem cell marker genes and proteins were alkaline phosphatase-positive. After reprogramming, the mutated genes were not altered and normal karyotypes were observed; Epstein-Barr viral genes were also not expressed. Most iPSC lines were confirmed to be able to differentiate into ectoderm, mesoderm and endoderm in vivo, indicating that we had successfully established iPSC lines. These iPSC lines were then induced to differentiate into cardiomyocytes. Most of these iPSC lines were observed to differentiate into beating cardiomyocytes, with some diversity in cardiomyocyte differentiation among the cell lines. In this study, we examined the effect of serial dilutions of agents on early stages of cardiomyocyte differentiation. In a floating culture system, varying concentrations of Activin A $(0-10 \mathrm{ng} / \mathrm{mL})$ and BMP4 $(0-10 \mathrm{ng} / \mathrm{mL})$ with FGF-2 $(5 \mathrm{ng} / \mathrm{mL})$ in StemPro 34 (ThermoFisher Scientific, Waltham, MA) medium

\footnotetext{
E. Hayama $(\bowtie) \cdot$ Y. Furutani $\cdot$ N. Kawaguchi $\cdot$ E. Oomichi $\cdot$ M. Shimada $\cdot$ K. Inai T. Nakanishi

Department of Pediatric Cardiology, Tokyo Women's Medical University, Tokyo, Japan e-mail: emiko-ha@twmu.ac.jp; nakanishi.toshio@twmu.ac.jp
} 
were used to induce mesoderm formation. The optimum concentrations of the agents for cardiomyocyte induction in iPSC lines were varied; $0-5 \mathrm{ng} / \mathrm{mL}$ Activin A and $1.25-10 \mathrm{ng} / \mathrm{mL}$ BMP4 were generally effective. We further investigated some additives for enhancement of embryoid body (EB) formation, and hyaluronate and Matrigel (BD Biosciences, San Jose, CA) addition relatively improved EB formation. Induction of functioning cardiomyocytes was associated with the ability to form appropriately sized EB in floating culture. Thus, further studies are required to improve the cell differentiation ability in some iPSC lines for establishment of stable disease models using patient-specific iPSC-derived cardiomyocytes.

Acknowledgment This work was supported in part by grants from the Japan Research Promotion Society for Cardiovascular Diseases.

Open Access This chapter is licensed under the terms of the Creative Commons Attribution 4.0 International License (http://creativecommons.org/licenses/by/4.0/), which permits use, sharing, adaptation, distribution and reproduction in any medium or format, as long as you give appropriate credit to the original author(s) and the source, provide a link to the Creative Commons license and indicate if changes were made.

The images or other third party material in this chapter are included in the chapter's Creative Commons license, unless indicated otherwise in a credit line to the material. If material is not included in the chapter's Creative Commons license and your intended use is not permitted by statutory regulation or exceeds the permitted use, you will need to obtain permission directly from the copyright holder.

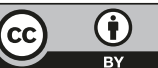

